\title{
Removal of nickel ions and methylene blue dyes from aqueous solutions using alkaline algae biomass
}

\author{
Aya Abbas Najim ${ }^{1, *}$, and Ahmed A. Mohammed ${ }^{2}$ \\ ${ }^{1}$ Department of Environmental Engineering, University of Baghdad, Baghdad, Iraq, ayaaabbas@yahoo.com \\ 2 Department of Environmental Engineering, University of Baghdad, Baghdad, Iraq, ahmed.abedm@yahoo.com \\ * Correspponding Author: Aya Abbas Najim,email: ayaaabbas@yahoo.com \\ Published online: 31 August 2019
}

Abstract- The sorption of nickel (II) and methylene blue dye (MB) from aqueous solution by alkaline treated algae biomass was investigated. $0.05 \mathrm{M} \mathrm{NaOH}$ resulted in increasing the removal efficiency of algae biomass from 77.48 to $97.43 \%$ and from 79.71 to $97.53 \%$ for Ni (II) and MB, respectively. Pseudo first order, pseudo second order and intra- particle diffusion kinetic models were tested, good coefficients of determination $\left(\mathrm{R}^{2}\right)$ were attained from pseudo second order kinetic model for both contaminants; therefore, chemical adsorption was the mechanism that governed the sorption process by alkaline treated algae. The data were best fitted to Langmuir isotherm model and a maximum sorption capacity achieved were 2.889 $\mathrm{mg} / \mathrm{g}$ for Ni (II) and $6.406 \mathrm{mg} / \mathrm{g}$ for MB. The separation factor shows irreversible isotherm type due to $\mathrm{R}_{\mathrm{L}}$ $<1$ for both contaminants. Alkali pretreatment of algae mixture could be an effective and low cost strategy for enhancing $\mathrm{Ni}$ (II) and MB sorption from aqueous solution.

Keywords - Biosorption, Algae biomass, Coefficient of determination, Methylene blue, Nickel (II).

\section{Introduction}

Water pollution is a major environmental problem faced by modern society that leads to ecological disequilibrium and health hazards [10]. Metals are known to be toxic and released into the environment in amounts that pose a danger to ecosystem, including mercury, cadmium, nickel, chromium, zinc, lead, selenium, silver and copper [9]. A significant threat to public health and the environment resulted from the exposure to these heavy metals, due to their toxicity, persistence in nature, and bioaccumulation in the food chain [16]. On the other hand, dyes is one of the significant classes of the pollutants, when enter the water it is no longer good and sometimes difficult to treat as they have a synthetic origin and a complex molecular structure which makes them more stable and difficult to be biodegraded [26]. Some of the conventional methods employed to reduce the pollutant content in the discharges include ion exchange, lime precipitation, electrolytic methods, membrane process, biodegradation, photocatalytic, photolytic, advanced oxidative degradation and adsorption onto activated carbon. All these methods are generally expensive $[18,8]$. Biosorption can be defined as the ability of biological materials (algae, bacteria, fungi and yeast) to accumulate contaminants from wastewater through metabolically mediated or physico-chemical pathways of uptake. Recently biosorption technique by using algal biomass is proven to be economical and beneficial to the environment. Compared to conventional treatment, biosorption have many advantages including high efficiency, low cost, no additional nutrient requirement, biological and/or chemical sludge can be minimized, regeneration of biomass, and metal recovery is possible.[1]

many problems have been observed by using untreated biomass as adsorbents like low adsorption capacity, high chemical oxygen demand (COD) and biological oxygen demand (BOD) as well as total organic carbon (TOC) as a result of releasing soluble organic compounds restricted in the biomass; so, the adsorbents need to be treated or modified before being used as adsorbent [24]. Several physical/chemical treatments had been used to enhance the uptake of organic and inorganic contaminant by algal biomass that provide additional binding sites by changing the cell wall properties of algae biomass. Algal biomass physical treatments like freezing, drying, heating, boiling, and crushing usually lead to improve the level of adsorbate biosorption. In general, algae chemically modified exhibit higher biosorption capacities than unmodified forms. The most common algal pretreatments are formaldehyde, $\mathrm{NaoH}, \mathrm{HCl}$, glutaraldehyde, and $\mathrm{CaCl} 2$ [33]. The 
treatment with alkaline is noticed as one of the widely active chemical treatment techniques for surface modification in order to improve its adsorption properties [26]. A few researchers have attempted to modify biomass chemically prior to its application for biosorption [21]. Bulgariu and Bulgariu, 2016 showed that alkaline treated algae waste biomass can be used effectively for large scale treatment of wastewater [7]. Kumar and Bandyopadhyay, 2006 treated rice husk adsorbent with $\mathrm{HCl}, \mathrm{NaOH}$, $\mathrm{NaHCO} 3$, and $\mathrm{C} 3 \mathrm{H} 5 \mathrm{ClO}$ to increase sorption capacity toward cadmium ions, the $\mathrm{NaHCO} 3$ gives the highest removal efficiency among other used solutions [18]. Pirbazari et al., 2014 showed that alkali treated Foumanat tea waste has high efficiency of in removing methylene blue dye from aqueous solution.[26]

The aim of this study was to quantify the efficacy of alkaline $(\mathrm{NaOH})$ pretreatment on the ability of mixed algae to sorb $\mathrm{Ni}$ (II) and $\mathrm{MB}$ dye and to investigate the time and concentration of treated material on the removal efficiency.

\section{Materials and methods}

\subsection{Material}

The algae biomass was collected from the artificial irrigation canal near college of engineering in Baghdad University. $0.5 \mathrm{~kg}$ of collected algae were analyses for their genus and species and percentage weight by using microscope in biological department, Ibn Al-Haitham college, university of Baghdad. The results showed that there were three divisions were dominated in this sample, the Chrysophyta algae was the highest percentage, and these results were listed in Table. 1. The collected materials were washed many times with water to remove the adhering dirt, impurities, and other unwanted materials finally two times with distilled water to ensure clearness. The washed algae were left under sun for three days to dry and then dried in oven at $60^{\circ} \mathrm{C}$ for $3 \mathrm{~h}$ to ensure that the sample dried completely. The dried algae ground and sieved into $177 \mu \mathrm{m}$. Pretreatment of the algae biomass was carried out as follows: A thirty grams of dry biomass $(177 \mu \mathrm{m})$ was treated with $500 \mathrm{ml}$ of $(0.05,0.1$ and $0.5 \mathrm{M})$ $\mathrm{NaOH}$ at $25^{\circ} \mathrm{C}$ for $1 \mathrm{hr}$ and then agitated on a shaker (ISO 9001, model: LSI-3016A, NO.B110416002, Korea) for 60 min at $50 \mathrm{rpm}$. After centrifugation, the biomass washed several times with distilled water until $\mathrm{pH} 7.0$ was reached, and then dried at $60{ }^{\circ} \mathrm{C}$ for 4 hours in the oven (model: F62700, Barnstead Thermolyne, Germany). Fig. 1 shows algae biomass pictures treated with different concentration of $\mathrm{NaOH}$.

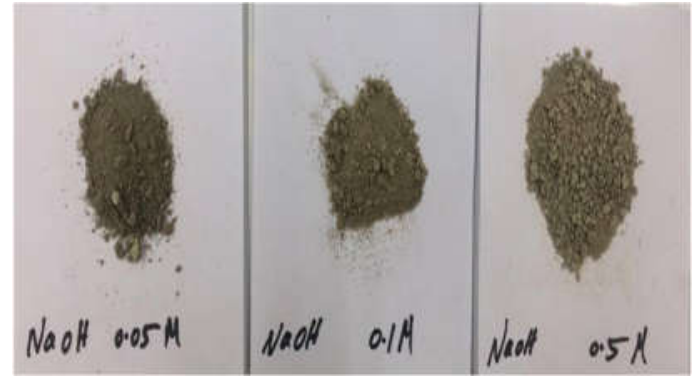

Figure 1: $\mathrm{NaOH}$ modify with different concentration to treat algae biomass

Table 1: Division, genus, species and weighting percentage of collected algae.

\begin{tabular}{|c|c|c|c|}
\hline Division & Genus & Species & $\%$ \\
\hline Chrysophyta & $\begin{array}{l}\text { Navicular } \\
\text { Cymbella } \\
\text { Nitzschia } \\
\text { Pinularia }\end{array}$ & $\begin{array}{l}\text { Many } \\
\text { species }\end{array}$ & $80 \%$ \\
\hline Cyanophyta & $\begin{array}{l}\text { Anabaena } \\
\text { Oscillatoria } \\
\text { phormidium }\end{array}$ & $\begin{array}{l}2 \text { species } \\
3 \text { species }\end{array}$ & $5 \%$ \\
\hline Chlorophyte & $\begin{array}{c}\text { Spirogera } \\
\text { Chlamydomonas } \\
\text { Cosmarim } \\
\text { Chlorella } \\
\text { Scenedesmus }\end{array}$ & 1 species & $14 \%$ \\
\hline $\begin{array}{l}\text { Microscopic } \\
\text { animals }\end{array}$ & & & $1 \%$ \\
\hline
\end{tabular}

\subsection{Organic and inorganic contaminants preparation}

Synthetic aqueous stock solution $1000 \mathrm{mg} / \mathrm{l}$ of methylene blue was prepared by dissolving $1.0 \mathrm{~g}$ of $\mathrm{MB}$ in $1 \mathrm{~L}$ of distilled water, and the concentration of MB used $(50 \mathrm{mg} / \mathrm{l})$ were obtained by dilution of the stock solution [29]. While for nickel aqueous stock solution $1000 \mathrm{mg} / \mathrm{l}$ was prepared by dissolving $4.955 \mathrm{~g}$ of Nickel nitrate hexahydrate in $1 \mathrm{~L}$ of distilled water, and the required concentration $(35 \mathrm{mg} / \mathrm{l})$ were gained by dilution of the stock solution. The $\mathrm{pH}$ of solution was adjusted by adding $0.1 \mathrm{M} \mathrm{HCL}$ or $0.1 \mathrm{M}$ $\mathrm{NaOH}$ to get the desired value. Dissolved metal and dye concentrations in solution were determined by a flame atomic absorption spectrophotometer AAS (Model: 210 VGP, USA), and UV visible spectrophotometer (Cary-100 conc., Varian, USA), respectively. The characteristic 
wavelength used in analysis is $232.0 \mathrm{~nm}$ for nickel ion and $662 \mathrm{~nm}$ for methylene blue. The biosorption capacity and removal efficiency were calculated as follows [3]:

$q_{e}=\frac{(C i-C e) V}{m}$

$\%$ Removal efficiency $=\frac{C i-C e}{C i} * 100$

Where $C_{i}$ and $C_{e}$ are the initial and equilibrium contaminants concentration in the solution $(\mathrm{mg} / \mathrm{l}), \mathrm{v}$ the volume of solution in (L), and $m$ the quantity of biomass applied in (g).

\subsection{Method}

The experiment on the effects of $\mathrm{pH}$ was conducted by mix-up $0.5 \mathrm{~g}$ adsorbent dosage (non-treated algae) with 50 ppm of MB and $35 \mathrm{mg} / \mathrm{l}$ solution at different $\mathrm{pH}(1-8)$, then the flasks were shaken at $200 \mathrm{rpm}$ for $2 \mathrm{hr}$. To examine the differences in removal efficiency between alkaline treated and free algae with time, the experiment was conducted by mixing $35 \mathrm{mg} / \mathrm{l}$ with $8 \mathrm{~g} / \mathrm{l}$ biomass dosage for $\mathrm{Ni}$ (II) and $50 \mathrm{mg} / \mathrm{l}$ with $6 \mathrm{~g} / \mathrm{l}$ for MB at $200 \mathrm{rpm}$ for $120 \mathrm{~min}$. Different concentrations of treated solution were used to study the effect of increasing alkaline concentration on the removal efficiency

\section{Kinetic and isotherm models}

The solution $\mathrm{pH}$ was adjusted to 5 for MB and 6 for $\mathrm{Ni}$ (II) ions. These values corresponded to the maximum sorption of test contaminants by untreated biomass in batch system. The cells were harvested at different time period and the $\mathrm{MB}$ and $\mathrm{Ni}$ (II) ion content in the filtrate was determined. The data for the time course of pollutants sorption were fitted to pseudo first order, pseudo second order and intraparticle diffusion models. In order to determine the adsorption isotherm of algae biomass for $\mathrm{MB}$ and $\mathrm{Ni}$ (II) adsorption, the sorption studies were carried out at $25^{\circ} \mathrm{C}$ [5]. Experimental isotherm is suitable for selection of the most appropriate sorbent, for describing adsorption capacity to enable calculation of the feasibility of this process for a given application, and for determination of requirements sorbent dosage. Furthermore, the isotherm plays a vital role in the design of sorption systems and predictive modeling procedures for analysis [18]. The Langmuir adsorption has been widely used adsorption isotherm for the adsorption of a solute from a liquid solution as cited in [13]. Langmuir equation relates the coverage of molecules on a solid surface at a fixed temperature. The Langmuir model assumes a monolayer adsorption of solutes onto a surface comprised of identical sites with homogeneous biosorption energy $[2,6]$.

$\frac{C e}{q e}=\frac{1}{q m b}+\frac{C e}{q m}$

$R_{L}=\frac{1}{1+b C 0}$

Where: $\mathrm{q}_{\mathrm{e}}$ is the sorbed contaminants on the biomass $\left(\mathrm{mg} \cdot \mathrm{g}^{-1}\right), \mathrm{q}_{\mathrm{m}}$ is the maximum sorption capacity for monolayer coverage $\left(\mathrm{mg} \cdot \mathrm{g}^{-1}\right), \mathrm{b}$ is the constant related to the affinity of the binding site $\left(\mathrm{L}^{\mathrm{mg}} \mathrm{g}^{-1}\right), \mathrm{C}_{\mathrm{e}}$ is contaminants concentration in the solution at equilibrium (mg. $\mathrm{L}^{-1}$ ), and $\mathrm{R}_{\mathrm{L}}$ is the separation factor.

Freundlich equation is derived to model the multilayer sorption and for the sorption on heterogeneous surfaces with a non-uniform distribution of biosorption heat over the surface [6]. The Freundlich isotherm theory states that the ratio of the amount of solute adsorbed onto a particular mass of sorbent to the concentration of the solute in the solution is not constant at different concentrations [32]. The heterogeneity of the surface and multilayer biosorption to the binding sites positioned on the surface of the biomass are considered in the Freundlich isotherm which is an empirical expression and expressed as follows [2]:

$$
\log q e=\log K+\frac{1}{n} \log C e
$$

Where $\mathrm{K}=$ adsorption capacity constant $\left(\mathrm{mg} \cdot \mathrm{g}^{-1}\right) \cdot 1 / \mathrm{n}=$ adsorption intensity constant. Both $\mathrm{K}$ and $\mathrm{n}$ are constants, being indicative of the extent of adsorption and the degree of non-linearity between solution and concentration, respectively. $1 / \mathrm{n}<1$ indicates normal biosorption, while a $1 / \mathrm{n}>1$ indicates cooperative adsorption [30].

\section{4. $\quad$ Results}

\section{1 pH effect}

The $\mathrm{pH}$ is a significant issue affecting the removal of contaminant from aqueous solutions [22], affect the function groups on the adsorbent surface, and determine the solubility of dyes in the aqueous medium [11,27]. The effect of solution $\mathrm{pH}$ on the sorption of $\mathrm{Ni}$ (II) ions and $\mathrm{MB}$ dye was examined by adjusting the $\mathrm{pH}$ in the range (1-8) as shown in Fig. 2. The initial $\mathrm{pH}$ values were investigated lower than 9.0 since insoluble nickel hydroxide starts precipitation from the solution at higher $\mathrm{pH}$ values [20], making true sorption studies impossible. The minimum removal efficiency was detected at low $\mathrm{pH}[\mathrm{pH}=1.0]$, the reason behind this behavior may be due to at high $\mathrm{H}^{+}$ concentration the adsorbent surface becomes more positively charged such that the attraction between adsorbents and both pollutants is reduced [25]. The binding sites, at $\mathrm{pH}$ close to 5 are negatively charged due to presence of carboxylic, hydroxyl and amino groups. The removal percentage of methylene blue (MB) reaches maximum at $\mathrm{pH} 5$, no significant altered beyond $\mathrm{pH} 5$ was observed because at higher $\mathrm{pH}$, the surface of adsorbent particles may be negatively charged which enhances the positively charged dye cations through electrostatics forces of attraction [13]. The observed values also agree well with the result obtained by [28]. In opposite for nickel ions biosorption increasing $\mathrm{pH}(1.0-6.0)$, the surface area becomes more negatively charged thus facilitating greater 
metal removal by algal biomass, due to the absence of hydrogen ions and this leading to increase the ability of establishing links between metal cations and algae biomass [33], and then at $\mathrm{pH}(7.0-8.0)$, the percentage removal decreases due to the formation of anionic hydroxide complexes $[17,12]$.

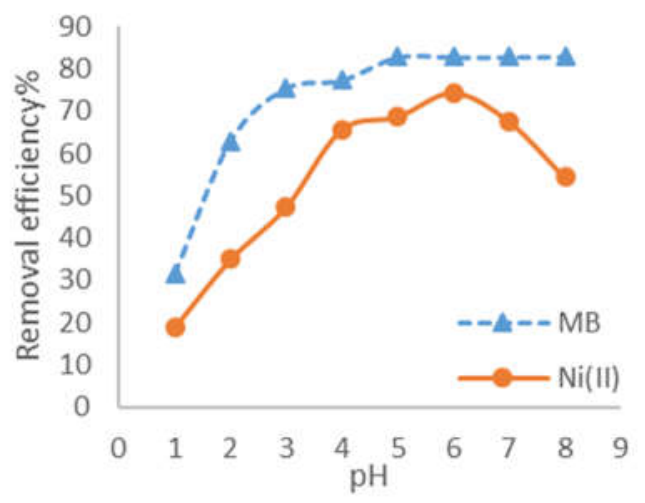

Figure 2: Effect of $\mathrm{pH}$ solution on removal efficiency of organic and inorganic pollutants at initial conditions ( $\mathrm{m}=0.5 \mathrm{~g} / 100 \mathrm{ml}, \mathrm{Ci}=35 \mathrm{mg} / \mathrm{l}$ for $\mathrm{Ni}$ (II) \& $50 \mathrm{mg} / \mathrm{l}$ for methylene blue, speed $=200 \mathrm{rpm}$, and time $=120 \mathrm{~min}$ )

\subsection{Effect of contact time and kinetics modelling}

Fig. 3 represent the kinetic removal of $\mathrm{MB}$ dye and $\mathrm{Ni}$ (II)

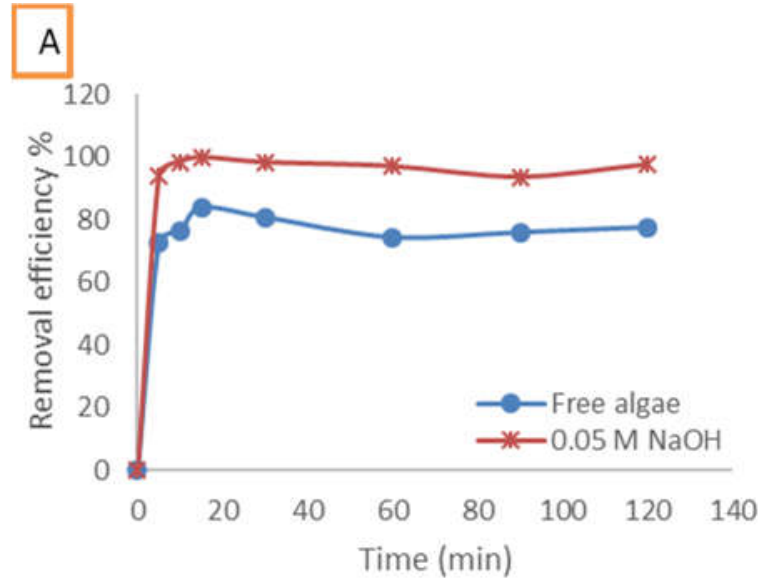

by virgin and alkali algae biomass. At each time interval, alkaline-pretreated algae sorbed more contaminants than the unmodified one. The sorption of MB and Ni (II) by modified algae attained the equilibrium within $15 \mathrm{~min}$, while for virgin algae the equilibrium achieved at $60 \mathrm{~min}$. Sodium hydroxide treatment of lignocellulosic materials can cause swelling which leads to an increase in internal surface area, a decrease in the degree of polymerization, a decrease in crystallinity, separation of structural linkage between lignin and carbohydrates, increase in the amount of galactouronic acid groups after hydrolysis of O- methyl ester groups, removes natural fats and waxes from the cellulose fiber surfaces thus revealing chemically reactive functional groups like ${ }^{-} \mathrm{OH}$, and disruption of the lignin structure $[23 ; 24]$. $\mathrm{NaOH}$ increase the electrostatic interactions of metal ion cations, and provides optimum conditions for ion- exchange [33]. Kinetic data of MB dye and Ni (II) sorption fitted very well (high coefficient of determination) by pseudo-second order model (Fig. 4) rather than pseudo first order and intra-particle diffusion models (Fig. not shown) and tabulated in Table. 2.

Figure 3: Time course of $\mathrm{Ni}$ (II) (A) sorption by alkaline treated and free algae at (35 $\mathrm{mg} / \mathrm{l}$ as initial concentration, $8 \mathrm{~g} / \mathrm{l}$ biomass concentration, $\mathrm{pH}=6.0) \& \mathrm{MB}(\mathrm{B})$ sorption at $(50 \mathrm{mg} / \mathrm{l}$ as initial concentration, $6 \mathrm{~g} / \mathrm{l}$ biomass concentration, $\mathrm{pH}=5.0)$

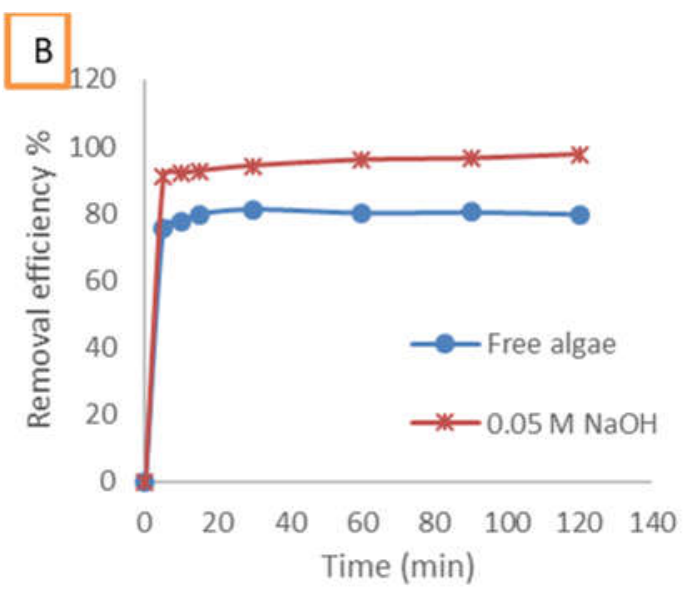



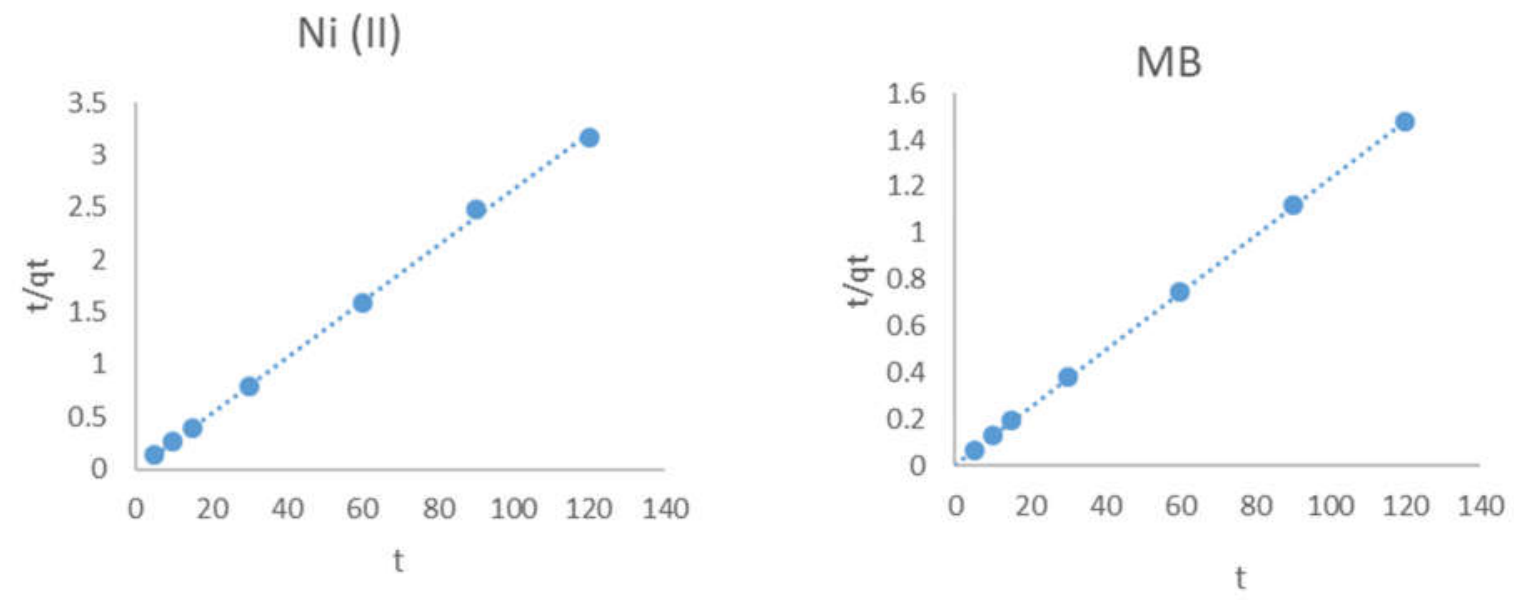

Figure 4: Pseudo-second order kinetic model for Ni (II) and MB dye

Table 2: Kinetics characterization of MB dye and Ni (II) biosorption onto alkaline treated algae biomass.

\begin{tabular}{|c|c|c|c|c|c|c|}
\hline \multirow{2}{*}{ Kinetic model } & \multirow{2}{*}{$\begin{array}{l}\text { Mathematical } \\
\text { equation }\end{array}$} & \multirow{2}{*}{ Notation } & \multicolumn{3}{|c|}{ Parameters values } & \multirow{2}{*}{ Reference } \\
\hline & & & & $\mathrm{Ni}$ (II) & MB & \\
\hline \multirow[t]{3}{*}{ Pseudo- first order } & \multirow[t]{3}{*}{$\operatorname{Ln}(\mathrm{qe}-\mathrm{qt})=\ln \mathrm{qe}-\mathrm{k} 1 \mathrm{t}$} & \multirow{3}{*}{$\begin{array}{l}\text { qe is the amount of both } \\
\text { contaminants retained on } \\
\text { weight unit of biosorbent at } \\
\text { equilibrium; qt is the } \\
\text { contaminant uptake capacity } \\
\text { ( } \mathrm{mg} / \mathrm{g} \text { ) at any time } \mathrm{t} \text {; } \mathrm{k} 1 \text { is the } \\
\text { pseudo-first order constant rate } \\
(1 / \mathrm{min}) \text {. }\end{array}$} & $\mathrm{R} 2=$ & 0.654 & 0.9745 & \multirow[t]{3}{*}{ [19] } \\
\hline & & & $\mathrm{K} 1=$ & 0.0182 & 0.0208 & \\
\hline & & & $\mathrm{qe}=$ & 0.139 & 5.643 & \\
\hline \multirow{3}{*}{$\begin{array}{l}\text { Pseudo-second } \\
\text { order }\end{array}$} & \multirow{3}{*}{$\frac{\mathrm{t}}{\mathrm{q}_{\mathrm{t}}}=\left(\frac{1}{\mathrm{k}_{2} \mathrm{q}_{\mathrm{e}}^{2}}+\frac{\mathrm{t}}{\mathrm{q}_{\mathrm{e}}}\right)$} & \multirow{3}{*}{$\begin{array}{l}\mathrm{k} 2 \text { is the observed rate constant } \\
\text { of pseudo-second-order kinetic } \\
\text { model }(\mathrm{g} / \mathrm{mg} . \mathrm{min})\end{array}$} & $\mathrm{R} 2=$ & 0.9992 & 0.9999 & \multirow[t]{3}{*}[15]{} \\
\hline & & & $\mathrm{K} 2=$ & -1.303 & 0.153 & \\
\hline & & & $\mathrm{qe}=$ & 4.199 & 8.1433 & \\
\hline \multirow{3}{*}{$\begin{array}{c}\text { Intra-particle } \\
\text { diffusion model }\end{array}$} & \multirow[t]{3}{*}{$\mathrm{qt}=\mathrm{kp} \mathrm{t} 1 / 2+\mathrm{C}$} & \multirow{3}{*}{$\begin{array}{l}\text { Kp is the rate constant of intra- } \\
\text { particle diffusion ( } \mathrm{mg} / \mathrm{g} \\
\text { min } 1 / 2), \mathrm{C} \text { is the value of } \\
\text { intercept which gives an idea } \\
\text { about the boundary layer } \\
\text { thickness. }\end{array}$} & $\mathrm{R} 2=$ & 0.4396 & 0.9755 & \multirow[t]{3}{*}{ [31] } \\
\hline & & & $\mathrm{K}_{\mathrm{p}}$ & -0.0197 & 0.0622 & \\
\hline & & & $\mathrm{C}=$ & 4.3922 & 7.4662 & \\
\hline
\end{tabular}

\subsection{Effect of $\mathrm{NaOH}$ concentration and equilibrium modelling}

It has been found that the treatment with $\mathrm{NaOH}$ creates additional basic sites for binding cations species [14]. The adsorption efficiency increase by using base modify material due to the negatively charged hydroxyl anions [4]. $\mathrm{NaOH}$ also improves chemical and mechanical properties of cellulose material like structural durability, natural ion- exchange capacity and reactivity [24]. A decrease in removal efficiency was observed as shown in Fig. 5, when the concentration of $\mathrm{NaOH}$ increased from 0.05 to $0.5 \mathrm{MA}$. The reason behind this observation was due to the destruction of biomass [24]. Isotherm data of MB dye and Ni (II) sorption fitted very well with Langmuir isotherm model (high coefficient of determination) rather than Freundlich model as shown in Fig. 6 and Table. 3. 
A

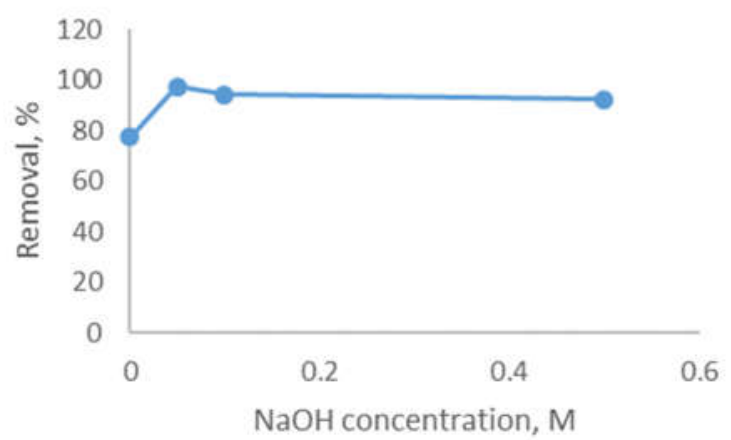

B

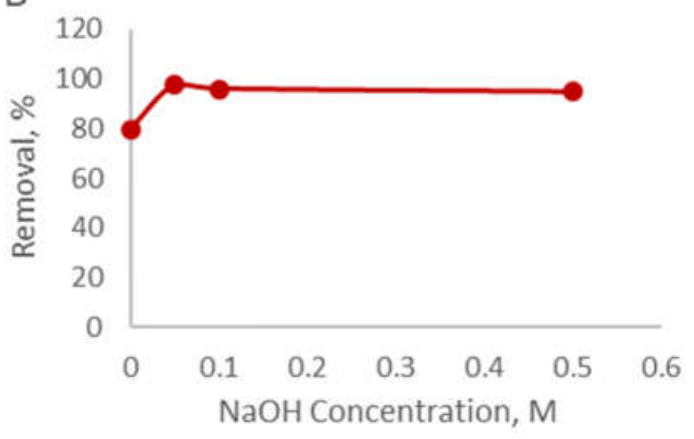

Figure 5: Effect of $\mathrm{NaOH}$ modify concentration on the removal efficiency for $\mathrm{Ni}$ (II) (A) at (35 mg/l as initial concentration, $8 \mathrm{~g} / 1$ biomass concentration, $\mathrm{pH}=6.0,177 \mu \mathrm{m}$ particle size, and $120 \mathrm{~min}$ ) \& $\mathrm{MB}(\mathrm{B})$ sorption at $(50 \mathrm{mg} / 1$ as initial concentration, $6 \mathrm{~g} / \mathrm{l}$ biomass concentration, $\mathrm{pH}=5.0,177 \mu \mathrm{m}$ particle size, and $120 \mathrm{~min}$ )

A

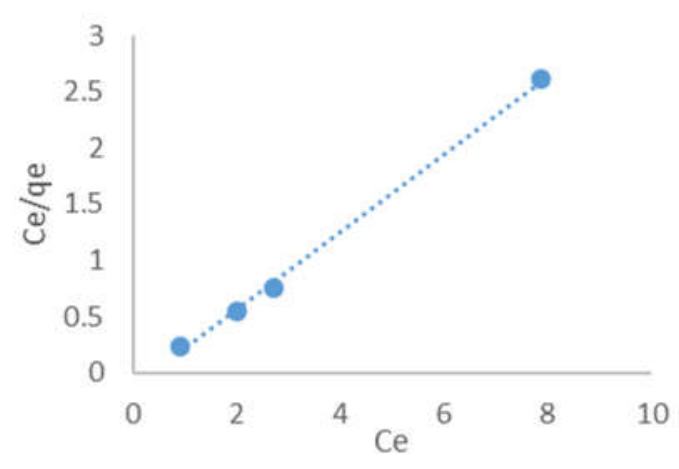

B

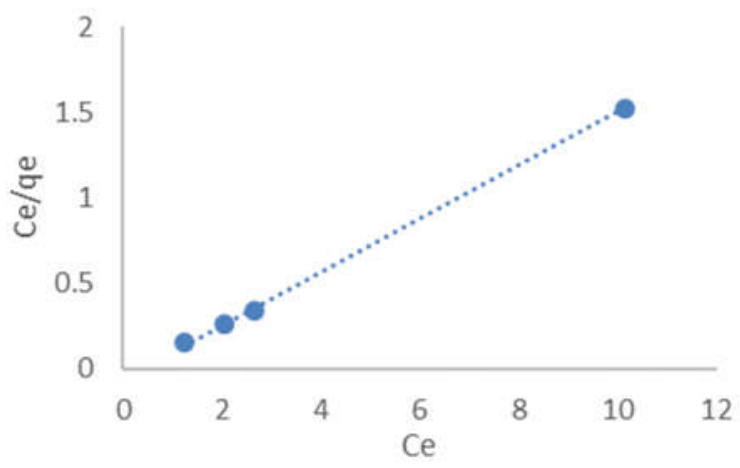

Figure 6: Langmuir isotherm model for $\mathrm{Ni}$ (II) (A) and MB (B) biosorption.

Table 2: Kinetics characterization of MB dye and Ni (II) biosorption onto alkaline treated algae biomass.

\begin{tabular}{|c|l|c|c|c|c|c|c|}
\hline \multirow{2}{*}{ Isotherm } & \multicolumn{4}{|c|}{ Langmuir } & \multicolumn{3}{c|}{ Freundlich } \\
\cline { 2 - 8 } & \multicolumn{1}{|c|}{$\mathbf{q}_{\mathbf{m}}$} & $\mathbf{b}$ & \multicolumn{1}{|c|}{$\mathbf{R}^{\mathbf{2}}$} & \multicolumn{1}{|c|}{$\mathbf{R}_{\mathbf{L}}$} & $\mathbf{K}_{\mathbf{f}}$ & $\mathbf{1} / \mathbf{n}$ & $\mathbf{R}^{\mathbf{2}}$ \\
\hline $\mathbf{N i}$ (II) & 2.889 & -2.68 & 0.9981 & -0.011 & 3.86 & -0.1079 & 0.896 \\
\hline $\mathbf{M B}$ & 6.406 & -2.61 & 0.9994 & $-7.7 \mathrm{E}-3$ & 8.506 & -0.1017 & 0.9462 \\
\hline
\end{tabular}

\section{Conclusions}

The present study may help in developing an efficient and economically feasible technology for removing organic and inorganic from aqueous solution. it shows that the alkaline algae biomass mixture could remove as much as 97.43 and $97.53 \%$ of Ni (II) and MB, respectively from solution containing $35 \mathrm{mg} / \mathrm{l}$ for $\mathrm{Ni}$ (II) and $50 \mathrm{mg} / \mathrm{l}$ for MB. The treated algae biomass attained equilibrium in $15 \mathrm{~min}$, which is short time compared to non-treated (virgin) algae that achieved equilibrium in $60 \mathrm{~min}$. Increasing the concentration of treated solution from 0.05 to $0.5 \mathrm{M}$ did not improve the removal efficiency, infect the removal percentage decrease as $\mathrm{NaOH}$ concentration increased. The Langmuir represent the data very well with $\mathrm{R}^{2}$ equal to 0.9981 and 0.9994 for $\mathrm{Ni}$ (II) and MB, respectively so it is a monolayer process. The parameter $1 / \mathrm{n}$ was less than 1 that indicates normal biosorption process. The data fitted with pseudo second order that assumed the rate limiting step may be chemical sorption.

\section{References}

[1] Ahalya, N., Ramachandra, T.V. and Kanamadi, R.D., 2003. Biosorption of heavy metals. Res. J. Chem. Environ, 7(4), pp.71-79.

[2] Akbari, M., Hallajisani, A., Keshtkar, A.R., Shahbeig, H. and Ghorbanian, S.A., 2015. Equilibrium and kinetic study and modeling of $\mathrm{Cu}$ (II) and $\mathrm{Co}$ (II) synergistic biosorption from $\mathrm{Cu}$ (II)- 
Co (II) single and binary mixtures on brown algae C. indica. Journal of Environmental Chemical Engineering, 3(1), pp.140-149.

[3] Annadurai, G., Juang, R.S. and Lee, D.J., 2002. Use of cellulose-based wastes for adsorption of dyes from aqueous solutions. Journal of hazardous materials, 92(3), pp.263-274.

[4] Argun, M.E. and Dursun, S., 2006. Removal of heavy metal ions using chemically modified adsorbents. $J$. Int. Environ. Appl. Sci, 1(1-2), pp.27-40.

[5] Bhatnagar, A. and Minocha, A.K., 2010. Biosorption optimization of nickel removal from water using Punica granatum peel waste. Colloids and Surfaces B: Biointerfaces, 76(2), pp.544-548.

[6] Bouras, H.D., Yeddou, A.R., Bouras, N., Hellel, D., Holtz, M.D., Sabaou, N., Chergui, A. and Nadjemi, B., 2017. Biosorption of Congo red dye by Aspergillus carbonarius M333 and Penicillium glabrum Pg1: Kinetics, equilibrium and thermodynamic studies. Journal of the Taiwan Institute of Chemical Engineers, 80, pp.915-923.

[7] Bulgariu, D. and Bulgariu, L., 2016. Potential use of alkaline treated algae waste biomass as sustainable biosorbent for clean recovery of cadmium (II) from aqueous media: batch and column studies. Journal of Cleaner Production, 112, pp.4525-4533.

[8] Das, A.P. and Swain, S., 2013. Algal Biosorption of toxic dye Methylene blue.

[9] El-Said, A.G., Badawy, N.A. and Garamon, S.E., 2010. Adsorption of cadmium (II) and mercury (II) onto natural adsorbent rice husk ash (RHA) from aqueous solutions: study in single and binary system. J Am Sci, 6(12), pp.400-409.

[10]Feng, N., Guo, X., Liang, S., Zhu, Y. and Liu, J., 2011. Biosorption of heavy metals from aqueous solutions by chemically modified orange peel. Journal of hazardous materials, 185(1), pp.49-54.

[11] Gautam, R.K., Mudhoo, A. and Chattopadhyaya, M.C., 2013. Kinetic, equilibrium, thermodynamic studies and spectroscopic analysis of Alizarin Red S removal by mustard husk. Journal of Environmental Chemical Engineering, 1(4), pp.1283-1291.

[12]Hajar, M., 2009. Biosorption of cadmium from aqueous solution using dead biomass of brown alga Sargassum sp. Chemical Engineering, 17(1)

[13]Han, R., Han, P., Cai, Z., Zhao, Z. and Tang, M., 2008. Kinetics and isotherms of neutral red adsorption on peanut husk. Journal of Environmental Sciences, 20(9), pp.1035-1041.

[14]Hisarli, G., 2005. The effects of acid and alkali modification on the adsorption performance of fuller's earth for basic dye. Journal of colloid and interface science, 281(1), pp.18-26.

[15]Ho, Y.S. and McKay, G., 1999. Pseudo-second order model for sorption processes. Process biochemistry, 34(5), pp.451-465.
[16] Igwe, J.C. and Abia, A.A., 2007. Adsorption isotherm studies of $\mathrm{Cd}$ (II), $\mathrm{Pb}$ (II) and $\mathrm{Zn}$ (II) ions bioremediation from aqueous solution using unmodified and EDTA-modified maize cob. Eclética Química, 32(1), pp.33-42.

[17] Kalyani, S., Rao, P.S. and Krishnaiah, A., 2004. Removal of nickel (II) from aqueous solutions using marine macroalgae as the sorbing biomass. Chemosphere, 57(9), pp.1225-1229.

[18] Kumar, U. and Bandyopadhyay, M., 2006. Sorption of cadmium from aqueous solution using pretreated rice husk. Bioresource technology, 97(1), pp.104109.

[19] Lagergren, S.K., 1898. About the theory of so-called adsorption of soluble substances. Sven. Vetenskapsakad. Handingarl, 24, pp.1-39.

[20]Lopez, A., Lazaro, N., Priego, J.M. and Marques, A.M., 2000. Effect of $\mathrm{pH}$ on the biosorption of nickel and other heavy metals by Pseudomonas fluorescens 4F39. Journal of Industrial Microbiology and biotechnology, 24(2), pp.146-151.

[21] Mehta, S.K., Tripathi, B.N. and Gaur, J.P., 2002. Enhanced sorption of $\mathrm{Cu} 2+$ and $\mathrm{Ni} 2+$ by acidpretreated Chlorella vulgaris from single and binary metal solutions. Journal of applied phycology, 14(4), pp.267-273.

[22] Mohammed, A.A. and Isra'a, S.S., 2018. Bentonite coated with magnetite $\mathrm{Fe} 3 \mathrm{O} 4$ nanoparticles as a novel adsorbent for copper (II) ions removal from water/wastewater. Environmental Technology \& Innovation, 10, pp.162-174.

[23] Ndazi, B.S., Karlsson, S., Tesha, J.V. and Nyahumwa, C.W., 2007. Chemical and physical modifications of rice husks for use as composite panels. Composites Part A: applied science and manufacturing, 38(3), pp.925-935.

[24]Ngah, W.W. and Hanafiah, M.A.K.M., 2008. Removal of heavy metal ions from wastewater by chemically modified plant wastes as adsorbents: a review. Bioresource technology, 99(10), pp.39353948.

[25] Onundi, Y.B., Mamun, A.A., Al Khatib, M.F. and Ahmed, Y.M., 2010. Adsorption of copper, nickel and lead ions from synthetic semiconductor industrial wastewater by palm shell activated carbon. International Journal of Environmental Science \& Technology, 7(4), pp.751-758.

[26] Pirbazari, A.E., Saberikhah, E., Badrouh, M. and Emami, M.S., 2014. Alkali treated Foumanat tea waste as an efficient adsorbent for methylene blue adsorption from aqueous solution. Water Resources and Industry, 6, pp.64-80.

[27] Puchana-Rosero, M.J., Lima, E.C., Ortiz-Monsalve, S., Mella, B., Da Costa, D., Poll, E. and Gutterres, M., 2017. Fungal biomass as biosorbent for the removal of Acid Blue 161 dye in aqueous 
solution. Environmental Science and Pollution Research, 24(4), pp.4200-4209.

[28] Ramakrishna, K.R. and Viraraghavan, T., 1997. Dye removal using low cost adsorbents. Water Science and Technology, 36(2-3), pp.189-196.

[29] Shao, H., Li, Y., Zheng, L., Chen, T. and Liu, J., 2017. Removal of methylene blue by chemically modified defatted brown algae Laminaria japonica. Journal of the Taiwan Institute of Chemical Engineers, 80, pp.525-532.

[30] Tran, H.T., Vu, N.D., Matsukawa, M., Okajima, M., Kaneko, T., Ohki, K. and Yoshikawa, S., 2016. Heavy metal biosorption from aqueous solutions by algae inhabiting rice paddies in Vietnam. Journal of environmental chemical engineering, 4(2), pp.25292535.

[31] Weber, W.J. and Morris, J.C., 1963. Kinetics of adsorption on carbon from solution. Journal of the Sanitary Engineering Division, 89(2), pp.31-60.

[32] Yu, Z., Qi, T., Qu, J., Wang, L. and Chu, J., 2009. Removal of $\mathrm{Ca}$ (II) and $\mathrm{Mg}$ (II) from potassium chromate solution on Amberlite IRC 748 synthetic resin by ion exchange. Journal of hazardous materials, 167(1-3), pp.406-412.

[33]Zeraatkar, A.K., Ahmadzadeh, H., Talebi, A.F., Moheimani, N.R. and McHenry, M.P., 2016. Potential use of algae for heavy metal bioremediation, a critical review. Journal of environmental management, 181, pp.817-831.

\section{ازالة ايونات النيكل وصبغة المثيل الزرقاء من المحلول المائي باستخدام كتلة حيوية من

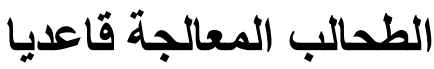

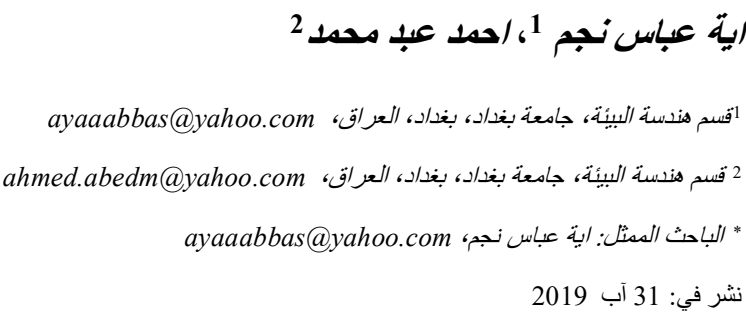

الخلاصة ـ تم فحص امتصاص صبخة الميثيلين الزرقاء و ايونات النيكل من محلول مائي بو اسطة الكتلة الحيوية للطحالب المعالجة بالقلويات.

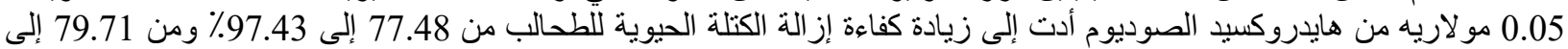

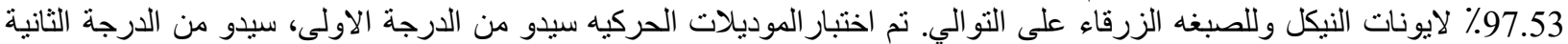

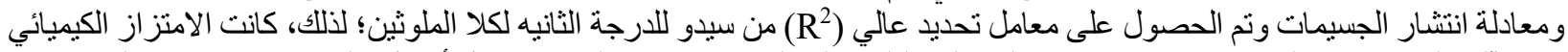

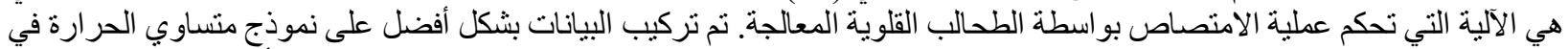

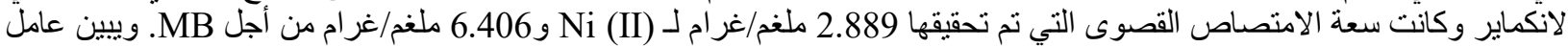

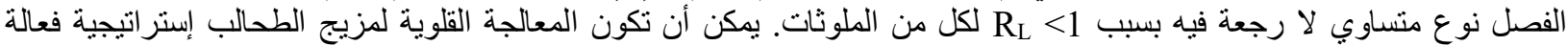

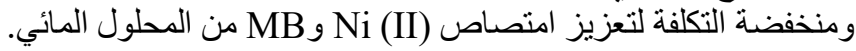
الكلمات الرئيسية ـ الإمتصاص البيولوجي، الكتلة الحيوية للطحالب، معامل التحديد، الأزرق الميثيلي، النيكل(II) . 